( О. Б. Книш, канд. техн. наук, доц., І. І. Регей, д-р техн. наук, проф., П. І. Бегень, канд. техн. наук, доц. , Українська академія друкарства, Львів, Україна

\title{
ДОСЛІДЖЕННЯ ІНЕРЦІЙНИХ НАВАНТАЖЕНЬ ПРИСТРОЮ ОБРОБКИ КОРІНЦІВ КНИЖКОВИХ БЛОКІВ У МАШИНІ НЕЗШИВНОГО СКРІПЛЕННЯ
}

\begin{abstract}
Проведено аналіз існуючих наукових доробків стосовно підготовки корінців книжкових блоків до нанесення клею перед виконанням незшивного клейового скріплення. Встановлено їх недоліки та запропоновано удосконалений спосіб та пристрій його реалізації, що не потребує додаткового електромеханічного привода.
\end{abstract}
Ключові слова: книжковий блок; інерційні навантаження; торцевий кулачок; потужність; привод; ланцюговий транспортер; швидкість.

\section{Постановка проблеми}

Станом на сьогодні переважну більшість (від 60 до 70 \%) книжково-журнальної продукції виготовляють із застосуванням незшивного клейового скріплення (НКС). Це можна пояснити низкою позитивних якостей способу, серед яких: здійснення поблочного скріплення; висока продуктивність обладнання за безупинної обробки півфабрикату; можливість інтегрувати обладнання НКС у потокові лінії спільно з агрегатами комплектування та тристороннього обрізування книжкових блоків.

Проте, серед недоліків такого способу скріплення книжкових блоків $€$ недостатня його міцність та довговічність порівняно 3, наприклад, шиттям нитками. Підвищувати міцність НКС можна декількома шляхами, а саме за- стосуванням нових рецептур клеїв або підвищенням якості підготовки корінців до їх нанесення [1]. Беручи до уваги потребу забезпечення необхідної міцності та довговічності книжкових блоків після НКС, актуальною $€$ задача удосконалення методів і засобів «розвинення» поверхні корінців блоків перед нанесенням на їх поверхню клею.

\section{Аналіз попередніх \\ досліджень}

Серед відомих способів обробки корінців книжкових блоків найбільшого розповсюдження зараз набули способи з обертовим рухом інструментів навколо вертикальної осі і контактуванням з корінцем торцевою ділянкою інструменту [2, 3]. Їх безсумнівною перевагою $€$ відсутність циклових механізмів та пов'яза-

() Автор(и) 2020. Видавець КПІ ім. Ігоря Сікорського.

CC BY 4.0 (https://creativecommons.org/licenses/by/4.0/). 
них з їхньою роботою знакозмінних навантажень, що дозволяє працювати за частоти до 6000 об/хв. Проте, недоліками $є$ значна споживана потужність (до 7 кВт) при застосуванні комплексного інструменту, що може включати різці, абразивні інструменті, дротяні щітки, високий рівень шуму при роботі та значне виділення паперового пилу.

У роботі [4] «розвинення» поверхні корінців пропонується здійснювати плоским ножем, що виконує плоско-паралельний рух у площині, яка нахилена під кутом до корінців. Таке розташування інструменту дозволяє виконувати дискретне нанесення на корінець характерних канавок з «вусиками». У працях [5, 6] автори розкривають можливість виконання обробки корінців застосуванням різців на дисках, що отримують приводи від циклових механізмів. Такі конструкції приводів провокують появу значних інерційних сил і додаткових навантажень на привод. У роботі [7] удосконалення НКС автори пропонують реалізувати за рахунок нанесення клею за технологією двостороннього розпуску аркушів, що ускладнює конструкцію машини. У працях $[8,9]$ авторами розкривається спосіб обробки корінців книжкових блоків ексцентриковими дисковими ножами. Проте, цей спосіб розглядається у контексті його втілення тільки для обрізування книжкових блоків.

Як засвідчив аналіз наукових публікацій, розглянуті методи не позбавлені недоліків. Тому у роботі [10] запропоновано новий спосіб обробки корінців книжкових блоків, що реалізується шля- хом контакту корінця з циліндричною фрезою, у якій вздовж твірних розташовано ножі. Такий принцип не потребує окремого електромеханічного привода секції; мінімізує шум та виділення паперового пилу. У роботі [11] проаналізовано конструкцію експериментального стенда, на якому підтверджено ефективність запропонованого способу і досліджено технологічні параметри його функціонування.

\section{Мета роботи}

Для підвищення ефективності розглянутого у працях [10, 11] способу запропоновано надавати фрезі у ході обертання при контакті з корінцем додаткового зворотно-поступального переміщення вздовж її осі. Метою статті $€$ обґрунтування нового способу нанесення канавок на корінець та дослідження кінематичних параметрів фрези для оцінки величини інерційних навантажень та їх впливу на сумарні навантаження роботи пристрою.

\section{Результати проведених досліджень}

Нанесення канавок на корінець книжкового блока запропоновано виконувати циліндричним інструментом з набором різальних лез (далі фреза). Надання додаткового зворотно-поступального переміщення фрезі вздовж осі її обертання забезпечить необхідну якість утворених канавок за рахунок зменшення деформації стиску паперу у зоні корінця та зменшить необхідний тиск з її боку на корінець, що зменшить навантаження на підшипникоопори та тягову силу переміщення 


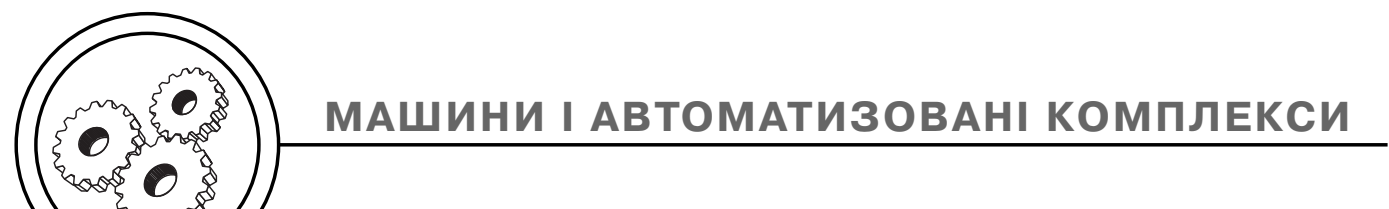

книжкового блока. Тому запропоновано схему пристрою для нанесення канавок з додатковим рухом інструменту (рис. 1).

Він працюе так. Книжковий блок КБ, затиснутий губками 1 транспортувальної системи, переміщується вздовж технологічних секцій машини НКС. При переміщенні він наштовхується на фрезу 2, яка оснащена різальними лезами 3 та обертається на валі 4. Вал в підшипникоопорах 5, 5' встановлено на станині машини 6 під кутом $\beta$ до напряму транспортування блока. Контактуючи з блоком фреза прокручується, а її леза залишають на його корінці канавки глибиною h. До вільного кінця валу на осі 9 закріплено ролик 8, який в ході обертання валу обкочує нерухомий дисковий кулачок 7. Внаслідок цього вал 4 з фрезою 2 отримують зворотно-поступальний рух вздовж осі обертання валу. Постійний контакт ролика 8 з кулачком 7 і повернення фрези 2 у початкове положення забезпечує пружина стиску 10.
Модернізація пристрою у такий спосіб зберігає основну перевагу прототипу, оскільки і надалі його конструкція не потребує додаткового привода, а обертовий і поступальний рухи фреза отримує внаслідок контакту з книжковим блоком.

До параметрів фрези можна віднести: зовнішній діаметр D (по вершинах різальних крайок); кількість різальних лез z; кут загострення лез $\alpha$. У результаті експериментальних досліджень параметрів утворення насічок визначено найбільш оптимальні розміри фрези $[\mathrm{X}]: \mathrm{D}=50 \mathrm{Mm}$, $z=17, \alpha=20^{\circ}$.

Визначимо величину лінійного переміщення $\mathrm{S}$ вершини різального леза фрези, при якому лезо знаходиться у контакті з книжковим блоком (рис. 2):

$$
S=2 \cdot \sqrt{\left(\frac{D}{2}\right)^{2}-\left(\frac{D}{2}-h\right)^{2}}
$$

де $\mathrm{h}$ - заглиблення леза у корінець книжкового блока.


Рис. 1. Принципова схема пристрою для утворення насічок на корінцях книжкових блоків з додатковим поздовжнім рухом фрези 


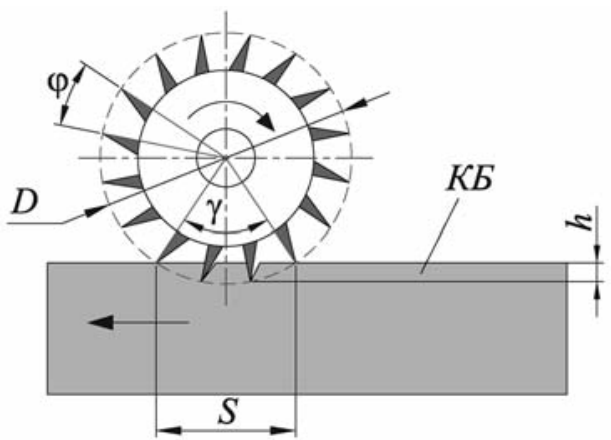

Рис. 2. Схема до визначення кількості лез фрези, які одночасно перебувають у контакті з книжковим блоком

Визначимо кількість лез, які одночасно перебувають у контакті $з$ книжковим блоком. Кут охоплення відстані S:

$$
\gamma=\arcsin \frac{0,5 \cdot S}{R}
$$

Кількість лез, які одночасно перебувають у контакті з книжковим блоком, визначається відношенням кута охоплення до кута між сусідніми лезами:

$$
z_{1}=\frac{\gamma}{\beta}=\frac{z \cdot \gamma}{2 \cdot \pi}
$$

На основі поведених експериментальних досліджень [11] було констатовано, що для ефективного зміцнення клейового скрі- плення блока канавки слід наносити глибиною від 0,4 мм до 1 мм залежно від виду паперу, клею. Для цього діапазону глибини канавок було встановлено кількість лез, що перебувають в одночасному контакті з блоком. Результати зведені у табл. 1.

Як бачимо, у кожному з випадків, у контакті перебуває щонайменше одне лезо, що виключає моменти, коли фреза може виходити з контакту з блоком, самовільно обертатися і після повторного входження у контакт порушувати визначений крок насічок. Максимальна кількість лез не перевищує двох, що не спричинятиме значного дисбалансу у коливанні навантажень при їх змінній кількості у зачепленні.

Таблиця 1

Кількість лез у контакті з книжковим блоком

\begin{tabular}{|l|c|c|c|c|c|}
\hline Глибина канавок & $\mathrm{h}, \mathrm{Mm}$ & 0,4 & 0,6 & 0,8 & 1 \\
\hline Лінійне переміщення & $\mathrm{S}, \mathrm{mm}$ & 8,91 & 10,9 & 12,5 & 14 \\
\hline Кут охоплення & $\gamma^{\circ}$ & 20,5 & 25,2 & 29,1 & 32,5 \\
\hline Кількість лез у контакті & $\mathrm{z}_{1}$, шт. & 1,2 & 1,47 & 1,7 & 1,9 \\
\hline
\end{tabular}


Синтезуємо профіль торцевого кулачка привода фрези, який забезпечує її осьове переміщення у ході прокочування по корінцю книжкового блока. Виходячи 3 максимальної товщини книжкових блоків, які скріплюють НКС, задаємо максимальне осьове переміщення фрези рівним $\mathrm{S}_{\Phi}=$ $=40 \mathrm{Mm}$.

Задаємо також умову, що переміщення і повернення у початкове положення повинно проходити за один повний оберт фрези. Визначимо шлях, який проходитиме книжковий блок за один оберт фрези, враховуючи глибину канавок:

$$
\mathrm{S}_{10 б}=\pi \cdot(\mathrm{D}-2 \cdot \mathrm{h}) \text {. }
$$

Кутова швидкість обертання фрези залежатиме від лінійної швидкості транспортування книжкових блоків $V_{5}$ i заглиблення лез у корінець:

$$
\omega_{\Phi}=\frac{V_{Б}}{0,5 \cdot D-h} .
$$

Обчислимо геометрію профілю торцевого кулачка, виходячи з описаних вище умов. Враховуючи особливості функціонування фрези, серед фазових кутів кулачка будуть відсутні фазові кути, що відповідають за зупинку вихідної ланки, а на кулачку будуть тільки ділянки віддалення і наближення фрези (фазові кути

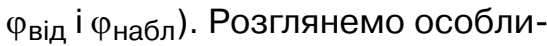
вості роботи фрези, при яких вона здійснює переміщення за наперед заданим законом періодичного руху (ЗПР).

Визначимо мінімальний радіус нування механізму за сприятливих кутів тиску. Для визначення кута тиску $v$ між напрямком вектору швидкості фрези і нормаллю до теоретичного профілю у точці контакту з роликом [12], наведено площинну розгортку профілю (рис. 3).

Мінімальний радіус кулачка, з врахуванням умови, що вздовж розгортки профілю L допустимий кут тиску $v$ не перевищує $30^{\circ}$, визначається:

$$
\mathrm{R}_{\mathrm{K}}=\frac{2 \mathrm{~S} \cdot \mathrm{B} / \mathrm{tgv}}{2 \pi} .
$$

де В - константа піка швидкості ЗПР. Значення мінімаль-
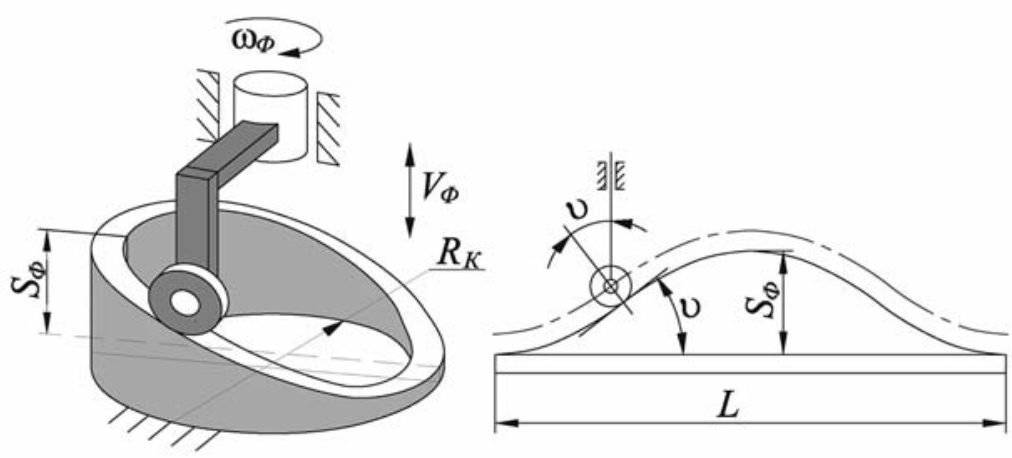

Рис. 3. Схема до визначення мінімального радіуса кулачка 
ного радіуса $R_{\mathrm{K}}$ для різних законів періодичного руху зведені у табл. 2.

Враховуючи, що кінематичний аналіз кулачкового механізму з зворотно-поступальною вихідною ланкою проходить у модульній системі [m, S, T], залежність для визначення інерційних навантажень переміщення фрези матиме вигляд [12]:

$$
F_{\mathrm{IH}}=\mathrm{C}_{\mathrm{k}} \frac{2 \cdot \mathrm{S}_{\Phi} \cdot \mathrm{V}_{\mathrm{5}}^{2}}{\mathrm{~S}_{\text {1об }}^{2}} \cdot \mathrm{m}
$$

де $\mathrm{S}_{1 \text { об }}$ - переміщення книжкового блока, при якому фреза здійснює один повний оберт; $\mathrm{m}$ маса фрези та інших рухомих елементів. Запропонована конструкція пристрою передбачає нерухомий кулачок і ролик, який прикріплений до осі фрези, і здійснює обертовий і зворотно-поступальний рухи. Таке рішення дозволить суттєво зменшити масу рухомих елементів для мінімізації інерційних навантажень. Сумарно маса фрези, осі її обертання та ролика із засобами його кріплення до осі складає 2,4 кг.

У ході аналізу кінематичних характеристик розглянуто ряд ЗПР, які застосовують у поліграфічному машинобудуванні для забезпечення необхідного характеру переміщення вихідної ланки [12]. Результати аналізу подано на рис. 4 у вигляді графіків залежності інерційних навантажень нерівномірного переміщення фрези у ході її обертання. Порівняльний графік побудовано при таких параметрах роботи пристрою: швидкість транспортування книжкового блока $\mathrm{V}_{5}=$ $=0,3 \mathrm{M} / \mathrm{c}$, занурення лез у корінець $\mathrm{h}=0,4$ мм, максимальне переміщення фрези $-\mathrm{S}_{\phi}=40 \mathrm{мm}$. Як бачимо з графіку, усі розглянуті ЗПР можна розділити на дві групи: з прискоренням і, як наслідок, силою інерції, що на початку циклу стартують 3 нуля, та 3 прискоренням і силою інерції, що стартують з певного значення. Проте, другому типу притаманні більші пікові значення сил

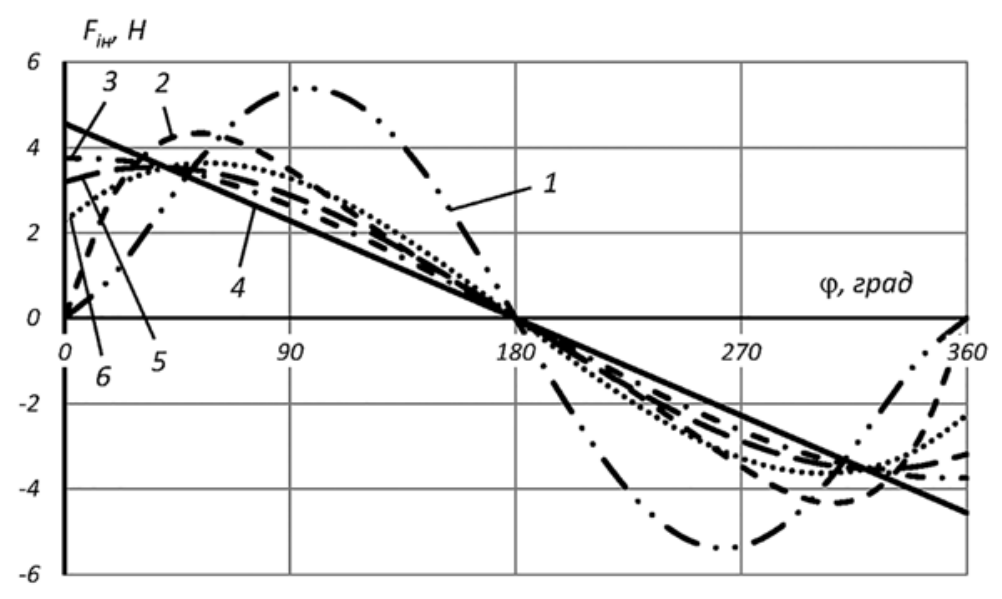

Рис. 4. Графіки інерційних навантажень осьового переміщення фрези (розшифрування кривих відображено у табл. 2) 
інерції. Тому, розглядаючи функціонування механізму привода фрези у комплексі дії інерційних і технологічних навантажень, при виборі раціонального ЗПР слід орієнтуватися на ЗПР з мінімальними піковими значеннями інерційних навантажень.

Пікові значення сил інерції та мінімальний радіус кулачка, знайдені за залежностями $(6,7)$, зведені у табл. 2. Як бачимо 3 табл., мінімальні пікові значення сили інерції виникають при застосуванні таких ЗПР, як Косинусоїда, Поліном 5-ї степені ( $\alpha=$ $=-3)$ та Поліном 5-ї степені ( $\alpha=$ $=-5)$. У той же час, мінімальний радіус кулачка, необхідний для реалізації, притаманний таким ЗПР: Косинусоїда, «0000», Поліном 5-ї степені $(\alpha=-3)$. Враховуючи два наведені вище критерії вибору, можемо рекомендувати до застосування у пристрої ЗПР Косинусоїда та Поліном 5-ї степені ( $\alpha=$ $=-3$ ).

Проведемо аналіз впливу на інерційні навантаження таких параметрів роботипристрою якшвидкість подачі книжкового блока та осьове переміщення фрези при ЗПР Поліном 5-ї степені. Перший параметр коливається від 0,3 м/с до 1,2 м/с, другий від 20 мм до 50 мм. Поряд з цим, зміна заглиблення лез у книжковий блок не впливатиме суттєво на значення інерційних навантажень, оскільки при застосуванні фрези діаметром 50 мм при збільшенні швидкості блока від 0,3 м/с до 1,2 м/с кутова швидкість її обертання, визначена за залежністю (4), зросте від 48,78 c-1 до $50 \mathrm{c}^{-1}$, тобто лише на 2,5\%.

Результати порівняльного аналізу відображено на графіках (рис. 5,6 ). Як бачимо з графіків, зміна швидкості транспортування суттєво впливає на зростання інерційних навантажень. Збільшення швидкості переміщення блока з 0,3 м/с до 1,2 м/с при осьовому переміщенні фрези на 0,04 м спричиняє зростання пікових значень сил інерції з 3,75 H до 58,97 Н, тобто майже у 16 разів (рис. 5).

Менше впливає на інерційні навантаження максимальний хід фрези. При його збільшенні 3

Таблиця 2

Значення піків сил інерції і мінімальних радіусів кулачків для розглянутих ЗПР

\begin{tabular}{|c|l|c|c|}
\hline & \multicolumn{1}{|c|}{ Назва 3ПР } & $\mathrm{F}_{\mathrm{iн} \max , \mathrm{H}}$ & $\mathrm{R}_{\mathrm{K} \text { min }}, \mathrm{Mm}$ \\
\hline 1 & Поліном 7-ї степені, $\alpha=6,6$ & 5,34 & 46,86 \\
\hline 2 & Поліном 7-ї степені, $\alpha=4,2$ & 4,33 & 37,21 \\
\hline 3 & Косинусоїда & 3,75 & 34,55 \\
\hline 4 & «0000» & 4,56 & 33,08 \\
\hline 5 & Поліном 5-ї степені, $\alpha=-3$ & 3,54 & 35,56 \\
\hline 6 & Поліном 5-ї степені, $\alpha=-5$ & 3,63 & 37,21 \\
\hline
\end{tabular}




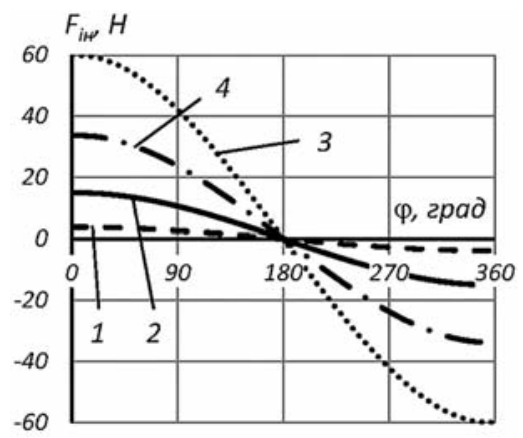

Рис. 5. Графіки залежності сил інерції від кута повороту фрези для швидкості транспортування блоків: 0,3 м/с (1), 0,6 м/с (2), $0,9 \mathrm{~m} / \mathrm{c}(3), 1,2 \mathrm{M} / \mathrm{c}(4)$

0,02 м до 0,05 м на швидкості блока 0,6 м/с спостерігаємо зростання пікових інерційних сил з $7,5 \mathrm{H}$ до $18,74 \mathrm{H}$, тобто у 2,5 рази (рис. 6).

Як бачимо з графіків, максимальне значення сили інерції становить 74,9 Н при виконанні насічок на корінці книжкового блока, який транспортується зі швидкістю 1,2 м/с при осьовому переміщенні фрези 0,05 м.

\section{Висновки}

Надання додаткового осьового переміщення фрезі при нанесенні канавок на корінці книжкових блоків дозволить підвищити їх якість. Проведено дослідження, у ході яких проаналізовано

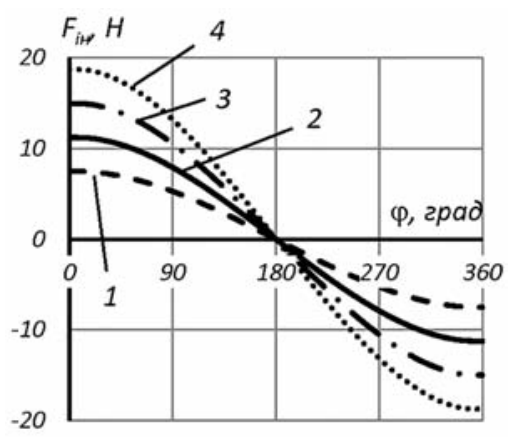

Рис. 6. Графіки залежності сил інерції від кута повороту фрези для осьового переміщення фрези: 0,02 м (1), 0,03 м (2), 0,04 м (3), 0,05 м (4)

вплив вибору закону періодичного руху фрези на інерційні навантаження та розміри кулачка. Виходячи з умови мінімізації пікових інерційних навантажень та габаритних розмірів кулачка запропоновано у механізмі застосовувати такі ЗПР: Косинусоїда та Поліном 5-ї степені $(\alpha=$ $=-3)$. Результати досліджень засвідчують, що включення додаткового механізму не нестиме значних додаткових навантажень на транспортну систему книжкових блоків, оскільки максимальні інерційні навантаження становлять від $1,87 \mathrm{H}$ до 74,96 Н. Найбільший вплив на їх зростання матиме збільшення швидкості транспортування книжкових блоків.

\section{Список використаної літератури}

1. Книш О. Б. Технологія обробки корінця книжкового блока при незшивному клейовому скріпленні / О. Б. Книш // Технологічні комплекси: науковий журнал. Луцьк: ЛНТУ. 2013. № 2(8). С. 95-99.

2. Протасьев В. Б. Особенности технологии фрезерования корешков бумажных блоков / В. Б. Протасьев, Л. А. Омельченко // Известия ТулГУ. Технические науки. 2012. Вып. 2. С. 442-448. URL: https://tidings.tsu.tula.ru/ tidings/pdf/web/file/tsu izv technical sciences 2012 02.pdf. 
3. Марченко И. В. Исследование прочности скрепления листов в корешке книжного блока при использовании PUR-клея / И. В. Марченко, О.П.Старченко // Труды БГТУ. Минск. 2013. № 8. С. 34-38. Режим доступу: https://elib.belstu.by/handle/123456789/6227.

4. Книш О. Б. Сучасні тенденції удосконалення засобів та пристроїв обробки корінця книжкового блока при незшивному клейовому скріпленні / О. Б. Книш, О. М. Полюдов // Наукові записки УАД: наук.-техн. збірник. Львів: УАД. 2014. № 3(48). С. 63-68. http://nz.uad.Iviv.ua/static/media/348/14.pdf.

5. Іванко А. І. Пристрій для зрізування корінцевих фальців у книжкових блоках при незшивному клейовому скріпленні / А. І. Іванко, Д. С. Гриценко // Комп'ютерні технології друкарства: наук.-техн. збірник. Львів: УАД. 2010. № 24. C. 241-247. http://www.ctp.uad.Iviv.ua/images//ktd/24_ivanko.pdf.

6. Іванко А. І. Автоматизоване проектування пристрою для обробки корінця книжкового блока засобами SolidWorks / А. І. Іванко, Д. Г. Кухарук // Технологія і техніка друкарства. 2011. № 4(34). C. 84-87. DOI: https://doi.org/10.20535/2077-7264.4(34).2011.33495.

7. Pasanec Preprotić S. Evaluation of binding strength depending on the adhesive binding methods / S. Pasanec Preprotić, I. Budimir, G. Tomić // Acta Graphica. 2015. 1-2(26). 20-27. URL: https://hrcak.srce.hr/file/214113.

8. Petriaszwili G. Wpływ parametrów pracy noża krążkowego ustawionego mimośrodowo na zmniejszenie trajektorii kontaktu ostrza z krojonym wkładem książkowym / G. Petriaszwili, P. Janicki, S. Komarov // Przegląd Papierniczy. 2019. 4(75). pp. 253-257.

9. Janicki P. Badanie trajektorii ruchu krawędzi tnącej noża krążkowego podczas krojenia wkładów książkowych / P. Janicki, G. Petriaszwili, S. Komarov // Opakowanie. 2017. № 9. pp. 76-79.

10. O. Knysh. Experimental researches of book blocks spine processing by cylindrical milling cutter during perfect binding / O. Knysh, I. Rehei, S. Ternytskii, N. Kandiak, P. Behen // Australian Journal of Mechanical Engineering. 2019. DOI: $10.1080 / 14484846.2019 .1625102$.

11. O. Knysh. Experimental evaluation of the tractive effort of the chain conveyor during book block spine processing by cylindrical milling cutter at perfect binding / O. Knysh, I. Rehei, N. Kandiak, S. Ternytskyi // Acta mechanica et automatica. 2019. vol. 13. no. 2. pp. 101-106. DOI 10.2478/ama-2019-0014.

12. Полюдов О. М. Розрахунки циклових механізмів поліграфічних і пакувальних машин на персональному комп'ютері (теорія, програми, інструкції): навчальний посібник / О. М. Полюдов, В. О. Кузнецов, А. Б. Коломієць. Львів: Вид-во УАД, 2004. 94 с.

\section{References}

1. Knysh, O. B. (2013). Tekhnolohiia obrobky korintsia knyzhkovoho bloka pry nezshyvnomu kleiovomu skriplenni [The Technology of Processing the Root of the Book Block with Non-Stitched Adhesive Bonding]. Tekhnolohichni kompleksy, 2(8), 95-99 [in Ukrainian].

2. Protasev, V. B. \& Omelchenko, L. A. (2012). Osobennosti tehnologii frezerovaniya koreshkov bumazhnyih blokov [Features of the Technology of Milling the Spines of Paper Blocks]. Izvestiya TuIGU. Tehnicheskie nauki, 2, 442-448. Retrieved from https://tidings.tsu.tula.ru/tidings/pdf/web/file/tsu_izv_technical_sciences_2012_02.pdf [in Russian].

3. Marchenko, I. V. \& Starchenko, O. P. (2013). Issledovanie prochnosti skrepleniya listov $v$ koreshke knizhnogo bloka pri ispolzovanii PUR-kleya [Study of 
the Bond Strength of Sheets in the Spine of a Book Block Using PUR Glue]. Trudy BGTU, 8, 34-38. Retrieved from https://elib.belstu.by/handle/ $123456789 / 6227$ [in Russian].

4. Poliudov, O. M. \& Knysh, O. B. (2014). Suchasni tendentsii udoskonalennia zasobiv ta prystroiv obrobky korintsia knyzhkovoho bloka pry nezshyvnomu kleiovomu skriplenni [Modern Tendencies of Improvement of Means and Devices of Processing of a Root of the Book Block at an Unstitched Glue Fastening]. Naukovi zapysky UAD, 3(48), 63-68. Retrieved from http://nz.uad.lviv.ua/static/media/3-48/14.pdf [in Ukrainian].

5. Ivanko, A. I. \& Hrytsenko, D. S. (2010). Prystrii dlia zrizuvannia korintsevykh faltsiv u knyzhkovykh blokakh pry nezshyvnomu kleiovomu skriplenni [Device for Cutting Root Folds in Book Blocks with Non-Stitched Adhesive Bonding]. Komp'iuterni tekhnolohii drukarstva, 24, 241-247 [in Ukrainian]. Retrieved from http://www.ctp.uad.Iviv.ua/images//ktd/24_ivanko.pdf [in Ukrainian].

6. Ivanko, A. I. \& Kukharuk, D. H. (2011). Avtomatyzovane proektuvannia prystroiu dlia ob-robky korintsia knyzhkovoho bloka zasobamy SolidWorks [Automated Designing of Device for Processing of Binding Edge with Facilities of SolidWorks]. Tekhnolohiia i tekhnika drukarstva, 4(34), 84-87. DOI: https://doi.org/10.20535/2077-7264.4(34).2011.33495 [in Ukrainian].

7. Pasanec Preprotić, S. \& Budimir, I. \& Tomić, G. (2015). Evaluation of binding strength depending on the adhesive binding methods. Acta Graphica, 1-2 (26), 20-27. Retrieved from https://hrcak.srce.hr/file/214113 [in English].

8. Petriaszwili, G. \& Janicki, P. \& Komarov, S. (2019). Wpływ parametrów pracy noża krążkowego ustawionego mimośrodowo na zmniejszenie trajektorii kontaktu ostrza z krojonym wkładem książkowym. Przegląd Papiernicz, 4(75), 253-257 [in English].

9. Janicki, P. \& Petriaszwili, G. \& Komarov, S. (2017). Badanie trajektorii ruchu krawędzi tnącej noża krążkowego podczas krojenia wkładów książkowych. Opakowanie, 9, 76-79 [in English].

10. Knysh, O. \& Rehei, I. \& Ternytskii, S. \& Kandiak, N. \& Behen, P. (2019). Experimental researches of book blocks spine processing by cylindrical milling cutter during perfect binding. Australian Journal of Mechanical Engineering. DOI: 10.1080/14484846.2019.1625102 [in English].

11. Knysh, O. \& Rehei, I. \& Kandiak, N. \& Ternytskyi, S. (2019). Experimental evaluation of the tractive effort of the chain conveyor during book block spine processing by cylindrical milling cutter at perfect binding. Acta mechanica et automatica, vol. 13, no. 2, 101-106. DOI 10.2478/ama-2019-0014 [in English].

12. Poliudov, O. M. \& Kuznetsov, V. O. \& Kolomiiets, A. B. (2004). Rozrakhunky tsyklovykh mekhanizmiv polihrafichnykh i pakuvalnykh mashyn na personalnomu komp'iuteri (teoriia, prohramy, instruktsii) [Calculations of Cyclic Mechanisms of Printing and Packaging Machines on a Personal Computer (Theory, Programs, Instructions)]. Lviv: Vyd-vo UAD, 94 p. [in Ukrainian].

\section{The analysis of existing scientific achievements for the pre- paration of book blocks for the glue application before}


the perfect binding is carried out. Their shortcomings are identified and an improved method and device for its implementation are proposed, which does not require an additional electromechanical drive.

Keywords: book block; inertia loads; end cam; power; drive; chain conveyor; speed.

\author{
Рецензент - О. В. Зоренко, канд. техн. наук, \\ доц., КПІ ім. Ігоря Сікорського
}

Надійшла до редакції 11.12.20 